Article

\title{
Toward Sustainability of South African Small-Scale Fisheries Leveraging ICT Transformation Pathways
}

\author{
Tsele T. Nthane ${ }^{1, * \mathbb{C}}$, Fred Saunders ${ }^{2}$, Gloria L. Gallardo Fernández ${ }^{2}$ and Serge Raemaekers ${ }^{1,3}$ \\ 1 Environmental and Geographical Science Department, University of Cape Town, Cape Town 7701, \\ South Africa; serge@abalobi.org \\ 2 School of Natural Sciences, Technology, and Environmental Studies, University of Södertön, \\ 14189 Huddinge, Sweden; fred.saunders@sh.se (F.S.); gloria.l.gallardo.fernandez@sh.se (G.L.G.F.) \\ 3 Abalobi NPO,1 Westlake Dr, Cape Town 7945, South Africa \\ * Correspondence: nthtse001@myuct.ac.za
}

Received: 14 October 2019; Accepted: 7 January 2020; Published: 20 January 2020

\begin{abstract}
Though Internet and Communication Technologies (ICTs) have been employed in small-scale fisheries (SSFs) globally, they are seldom systematically explored for the ways in which they facilitate equality, democracy and sustainability. Our study explored how ICTs in South African small-scale fisheries are leveraged towards value chain upgrading, collective action and institutional sustainability - key issues that influence small-scale fishery contributions to marine resource sustainability. We held a participatory workshop as part of ongoing research in the town of Lambert's Bay, South Africa, in collaboration with small-scale fishers and the Abalobi ICT project. We mapped fisher value chain challenges and explored the role of ICT-driven transformation pathways, adopting Wright's 'Real Utopian' framework as the lens through which to explore equality, democracy and institutional sustainability. We found Abalobi's ICT platform had the potential to facilitate deeper meanings of democracy that incorporate socio-economic reform, collective action and institutional sustainability in South Africa's small-scale fisheries. Where fishers are not engaged beyond passive generators of data, this had the potential to undermine the goals of increasing power parity between small-scale fisheries and other stakeholders.
\end{abstract}

Keywords: small-scale fisheries; sustainability; ICT4F; South Africa; value chains; Real Utopias; technology; co-design

\section{Introduction}

Small-scale fisheries are essential to the livelihoods of rural coastal communities by providing both food security and employment [1,2]. Yet, South African small-scale fisheries remain marginalized with the state chronically under-resourced and unable to adequately cater to their needs. Key reasons are that fishers commonly target low value species [3,4], fisher landing sites are remote and spread across multiple actors [5] making them difficult to manage, and South African fisheries is saddled with the legacies of Apartheid in which traditional fishers remain socio-economically marginalized [6-8].

Beyond employment and food security, small-scale fishing activities are deeply interwoven with local cultural practices and traditions [9], where retention of subsistence catch is commonly used in non-profit exchanges for help with landing tasks or shared amongst friends and family members [10]. Fishing practices have historically played a crucial role in the economic and socio-cultural development of rural coastal communities, thus raising important questions of the consequences when these practices are altered through private rights regimes, external actors and marine resource depletion [11]. Small-scale practices have been shown to exhibit traits antithetical to behavioral assumptions of self-interested actors, with actors willing to change the distribution of material outcomes at personal 
cost and displaying concern for fairness and reciprocity [12]. For the fishers of Lambert's Bay, South Africa, fishing practices around 'Snoek' (Thyrites atun) and other linefish species have shaped the community's livelihood and cultural practices over centuries [13], which thus bear importance on collective action possibilities and the design of interventions [12].

Research has commonly focused on small-scale fishery policy and governance, value chain upgrading and the application of Internet and Communication Technologies (ICTs) [14-18]. Value chain research is primarily interested in revealing dominant power relations between actors, the terms of inclusion and exclusion, and more recently, incorporating 'horizontal' dimensions such as gender, the environment and sustainability [18-21]. Despite the proliferation of ICT for Fisheries (ICT4F) interventions, little work has been conducted on ICT-supported transformation possibilities that shift power relations within existing governance and market structures $[22,23]$ within particular SSF settings or sought closer alignment with the ambitions of fisheries-related Sustainable Development Goals (SDGs) including: no poverty, zero hunger, gender equality, climate action and sustainability of life below water [24,25].

The urgency for systematically developed and contextually refined small-scale fisher transformation pathways is further apparent when understood in the context of decades of Apartheid and subsequent neoliberal fisheries policy that disenfranchised South African small-scale fishers [6-8,26-28]. We put forward that sustainability of marine resources must be facilitated by the design of institutions and governance arrangements that benefit small-scale fishers. We thus explore how small-scale fishers leverage ICT4F towards more democratic, equal and ultimately sustainable pathways.

\subsection{Struggles of the Marginalized in South Africa Post-1994}

South Africa held its first democratic elections in 1994, yet despite the promises and expectations of socio-economic redress, and the myriad programs directly and indirectly tethered to ideals of affirmative action, the patterns of inequality inherited from Apartheid remain $[6,7,29,30]$. Though progressive legislation such as the Bill of Rights and South Africa's much lauded Constitution have been enacted, the dire state of redress has precipitated a 'waiting' where the marginalized continue to wait on the delivery of the promises of socio-economic redress [31]. The majority of South African small-scale fishers live and harvest on rural coasts, while their struggles for access rights are fought in the large metropolis of Cape Town, where the headquarters of the State fisheries department is located.

Fisher protest action over the preceding two decades took place amidst the groundswell of public discontent, with fisher movements aligning themselves with trade unions and the struggles of the urban poor attempting to transform political spaces [32]. At the heart of small-scale fisher protests and broader social movements was dissatisfaction with the lack of socio-economic transformation despite the achievements of post-1994 political democratization [29].

\subsection{South African Small-Scale Fisheries}

South African societies are specific in the enormous expectations residents hold of the post-Apartheid state; this includes demands from artisanal fishers for universal access to marine resources [33]. South Africa's first democratic elections ushered in hopes of radical social, political and economic reforms in the fisheries sector. Industrialization of the sector in the 1950s had concentrated fishing rights in the hands of a few large industrial companies whilst systematically excluding artisanal fishers-restricting them to low-wage labor as crew and fish factory workers. Thus, the democratic government's first attempt at transformation of fisheries occurred between 1994-2007 with the Marine Living Resources Act of 1998 (MLRA), that sought to balance the needs of the industrialized commercial fishing sector with broadening access for artisanal fishers [6,34]. To retain their individual transferrable quotas (ITQs) under the MLRA, established companies were required to satisfy diversity requirements with the goal that ITQ redistribution to artisanal fishers would broaden access [8,35]. 
However, without infrastructural, financial and business skills to manage quota, artisanal fishers were often reduced to catching, processing and marketing agreements with larger industrial companies that reduced artisanal fishers to 'paper' quota holders without any real participation [36]. In addition, the MLRA recognized only a small-scale commercial fishing sector and made no provision for the men and women who derived a subsistence livelihood from marine resources. In effect, this excluded the majority of small-scale fishers who had, for generations, harvested marine resources [7].

Through a coalition of small-scale fishers, NGOs and university researchers, in 2004, the MLRA was challenged in the South African courts in "Kenneth George and Others vs. the Minister" [26]. Before a decision was reached by the Courts in 2007, the Minister settled, out of court, in an agreement that mandated the department to develop a policy, specific to the inclusion of small-scale fishers, in recognition of their historical livelihood dependence on marine resources [6]. Further, interim fishing licenses were immediately established that allowed small-scale fishers to harvest a limited amount of marine resources until the eventual promulgation of a new inclusive policy [37]. The result was the Small-Scale Fisher Policy of 2012 (SSFP) which provided the guidelines for the formal recognition and provision of South Africa's small-scale fishers.

The purpose of the new Small-Scale Fisheries Policy was to provide a framework under which small-scale fishers across all four of South Africa's coastal provinces could be granted collective community fishing rights with access to a 'basket' of resources [38]. As the legislative framework was finalized in 2016, the Department of Agriculture, Forestry and Fisheries (DAFF) spent the intervening period addressing contentious issues across South Africa's small-scale fisher communities, such as which men and women qualified as 'bona fide' fishers and thus could be provided for under the new policy. Simultaneously, this slow process forced small-scale fishers to organize, independently from the state, starting cooperatives and partnering with NGOs. One such NGO was Abalobi: a hallmark project that sought to leverage small-scale fisher data to facilitate value chain upgrading as one of multiple strategies to transform South African small-scale fisheries.

\subsection{Value Chains of Small-Scale Fisheries of the Western Cape, South Africa}

With $90 \%$ of South Africa's linefish caught within the Western Cape Province, small-scale fishers from Lambert's Bay contribute substantially to linefish harvests both through catches and as fish workers. Low-value species make up the majority of small-scale fisher catches with Snoek (Thyrsites atun), the largest contributor to fisher income and catch volumes [13]. Where Lambert's Bay fishers do harvest high value species such as Lobster (Jasus lalandii), these value chains remain linked to international Asian markets, with fishers unable to renegotiate their terms of incorporation and unable to influence the terms of trade [39].

Despite the importance of value chains to the sustainability of small-scale fisher livelihoods and the marine resource, state fisheries governance has not provided enough support to develop new, more viable small-scale fisher value chains nor the platforms for fishers to participate equitably in their existing value chains. The 2012 Small-Scale Fisher Policy represented the State's latest attempt at providing for small-scale fishers, promising economically viable access rights to all bona fide small-scale fishers. However, by 2019 , the state had still not comprehensively provided small-scale fishers with viable access rights nor the platform to advance more equitable value chain participation. Consequently, small-scale fishers explored alternative value chain upgrading pathways with the assistance of non-state actors, an increasingly pivotal trend largely directed at facilitating value chain upgrading through ICTs and direct marketing arrangements.

\subsection{Abalobi ICT4F Project}

Through collaboration between small-scale fishers, University of Cape Town researchers, and with support from telecom companies, the Abalobi project initiated an Internet and Communication Technology for Fisheries (ICT4F) platform in 2015. The project sought to address 'social justice and poverty alleviation' in South African small-scale fisheries, aiming to transform fisheries science to 
include fisher experiential knowledge, develop locally-based systems of marine resource stewardship and build socio-ecological resilience primarily through collecting reliable small-scale fisheries data [40].

ICT4F applications have grown more complex in their aims since the earliest landmark studies showed how mobile phones reduced information search costs and price dispersion for small-scale fishers of Kerala [17,41]. Where ICT applications were implemented, they commonly provided extension services for price, weather, pest and technical information, though they are increasingly offering more complex services linking buyers to sellers and offering financial services [18,42,43]. The rise of more comprehensive ICT offerings for small-scale fishers has occurred simultaneously with the increased focus on ICT applications that better meet the local context of participants [43]. This focus on improving ICT practice is intended to achieve higher success rates by including participants early in the design of the ICT intervention to encourage buy-in, legitimacy of the programs, as well as more accurately directed practice $[44,45]$.

The Abalobi platform consisted of five modules, namely: 'Fisher', 'Monitor', 'Manager', 'Co-op' and 'Marketplace'. Abalobi 'Fisher' was the core module and collected small-scale fisher logbook data. 'Monitor' was utilized by South African fisheries staff for catch monitoring. 'Manager' provided real-time fisheries data communication between small-scale fishers and Abalobi managers. 'Co-op' hosted collective accounting and asset management functions for small-scale fisher cooperatives, and 'Marketplace' captured small-scale fisher socio-cultural 'stories' on a traceability platform where fishers availed their catch for the Restaurant Supported Fishery (RSF). This 'storied' fish was modelled on the rapidly expanding arena of small-scale fisher direct marketing that facilitates shorter value chains between fishers and schools, hospitals, restaurants and homes [46-52]. At the time of writing, the most active modules were the Abalobi 'Fisher' and 'Marketplace' modules, with 'Monitor', 'Manager' and 'Co-op' in development.

Smartphones and ICTs are increasingly recognized as a tool for participatory fisheries data collection with the potential to increase the accuracy of small-scale fisheries data, facilitating communities in achieving sustainable development, an improved quality of life and supporting the poor and excluded $[5,53,54]$. Where small-scale fisheries data is collected, it is often irregularly so [54] or fails to fully capture the characteristics and essence of small-scale fisheries $[55,56]$. Whilst collecting reliable small-scale fisheries data remains imperative, the lack of public policies for the sector as well as the lack of skills in collecting this data continue to complicate the task $[57,58]$.

In the absence of reliable small-scale fisher data, researchers risk masking small-scale fisher importance by under- or overreporting resource availability which ultimately influences fisheries legislation [5]. In order to leverage this data effectively in support of transformation pathways, it is imperative that a systematic approach is adopted that examines the potential of ICTs to shift power relations in governance and market structures.

Fisher livelihoods remain intricately connected with the health of the oceans, raising the importance of new approaches that encompass biological stock, socio-economic and socio-cultural assessments, ushering in a renewed focus on participatory and interdisciplinary approaches that incorporate fisher knowledge [58]. While stock assessments retain prime importance in fisheries management, this prominence is being challenged as calls to include social and economic livelihood data increase [59-62]. One avenue to achieving broader indicators of marine resource health is incorporating fisher knowledge [63-66].

Though novel, the Abalobi project is indicative of broader momentum within the field of Internet and Communication Technologies for Fisheries (ICT4F). This includes Fish Trax, an electronic fishery information system for small-scale fisheries; Norpac Fisheries Export, which provides traceability services for small-scale fisheries; ThisFish, which connects small-scale fishers directly to end markets; and Trace Register, which is a web-based traceability application facilitating direct marketing between fishers and their end markets. 


\subsection{ICT 4 Fisheries}

ICTs were initially heralded as tools to 'leapfrog' underdeveloped communities by bridging the 'digital divide' towards more developed states, primarily through the proliferation of tele-centers located in rural areas. However, it quickly became apparent that tele-centers far underachieved their intended goals, and that ICT access often mirrored and thus, reinforced existing socio-economic inequalities. Yet the potential for ICTs to facilitate more robust rural livelihoods remains apparent, and it is thus critical to systematically investigate how and under what conditions ICTs are leveraged successfully towards the socio-economic development of rural communities, and in particular small-scale fisheries. We further need to build towards developing small-scale fisher criteria for selecting appropriate marine fishery ICT tools [66].

ICT interventions are extending beyond needs based design that focuses on short to medium term necessities, towards designing for long term aspirations [67]. Despite the proliferation of ICT studies, there remains a dearth in ICT research that provides positive evidence of successful outcomes of ICTs for environmental issues such as climate change and socio-ecological resilience [68]. Though collecting small-scale fisher data is a critical global priority, this can also have the effect of increasing the concentration of power in the hands of the few with the resources to access, analyze and extract meaning from it [69], raising questions of power between those who generate the data and those who effectively have control over it.

ICT interventions need to look beyond resolving issues of access and resources to that of wellbeing and fulfilment for the marginalized [70]. This entails defining how projects define development: whether development is defined as increased freedoms in the capabilities tradition, as expanded access to ICT artefacts for the disenfranchised, as increased economic productivity such as business profit through ICT use, or as improved wellbeing measured by satisfaction and fulfilment stemming from an ICT intervention [71]. Alternatively, development can also compellingly be defined as an increase in power parity between the stakeholders and beneficiaries [71], particularly because projects often privilege technical functionality over stakeholder engagement [72].

\subsection{Neoliberalism in Small-Scale Fisheries}

Neoliberal policies seek to control access to fisheries resources by strengthening property rights and reducing fishing effort in order to prevent marine resource overexploitation-typically through the introduction of Individual Transferrable Quotas (ITQs) [73]. With 'too many boats chasing too few fish', turning access into private property was intended to induce better stewardship of the resource whilst ensuring rights holders remained commercially vested in the health of the marine resource $[74,75]$. Though neoliberalism has increased profits generated through ITQs, these tend to remain concentrated in the hands of a few powerful actors at the exclusion of artisanal and indigenous fishers [76-78]. With assumptions rooted in the tragedy of the commons [78], small-scale fisheries were marginalized as industrial fisheries benefitted from the introduction of access rights and large quotas and subsidies [79]. For instance, of $\$ 35$ billion worth of subsidies issued globally in 2009, small-scale fisheries received only 16 percent [80].

With the majority of South Africa's small-scale fishers residing along rural coasts, it remains an obvious problem that neoliberalism consolidated wealth and power into urban and industrial fishing operations and away from customarily governed open-access fishing on which small-scale fishers depend. These geographic and economic shifts led to detrimental effects undermining coastal livelihood identities, cultural values and artisanal indigenous fishery practices [12,76,81,82]. Urban concentration of fishing rights tends to empower privileged social groups, further increasing wealth and class disparities [78,83], in addition to the prevalent role of speculative finance in undermining and disrupting sustainable practices in small-scale fisher communities [73].

Inequitably distributed fishing rights have precipitated crises of legitimacy with artisanal fishers contesting the legitimacy of fishing rights bureaucracies [76,78] and their rights holders, particularly where these rights holders had no historical stake in the marine resource [83]; or when 
women have not been included [84]. Those impacted are commonly fishers closest to the resource such as small-scale fisher skipper-operators, their crew and those further along the fisheries value chain [76]. This dispossession can lead to a unique form of wildlife crime where previously accepted SSF subsistence practices become illegal in the absence of legislation that supports their livelihoods and cultural practices [85].

In response to these problems, new forms of fisheries governance emerged that encouraged sustaining marine resource diversity and coastal livelihoods by exploring indigenous modes of custodianship [86], or by institutionalizing collective management and action; for example, through territorial use rights for fisheries (TURFs) $[87,88]$. Inspired by indigenous small-scale fisher movements resisting overfishing, development projects in their territories and exploring pathways that bypass corporate fish processors [73], alternative pathways to capital intensive fisheries have sought to reposition fisherfolk as community actors integral to rural economies [89,90]. In addition, non-state actors are continually emerging as key partners of small-scale fisher resistance [90], as well as facilitators in the development of transformative fisher pathways. By undermining small-scale fisher livelihoods, neoliberalism jeopardizes the sustainability of community livelihoods and the resources on which they depend.

\section{7. 'Real Utopias'}

In order to explore the potentiality of a pathways approach to transformation for South African SSFs, here we engage with Wright's 'Real Utopias' framework as a means to support progressive social change. Wright argues that states have grown complex and incapable of addressing novel problems of contemporary society [91], and by considering alternative economic and social systems, utopian alternatives create better conditions for human flourishing than those under capitalism [92]. Using utopian framing, we can begin to imagine how things could be when the problems in contemporary society are resolved, thus providing us with immediate actionable tasks in pursuit of a better future [93]. At the heart of Wright's 'Real Utopias' is the fundamental goal to transform power relations and encourage equality, democracy and sustainability in the establishment of alternative transformation pathways.

Equality equates with living a 'flourishing life' through grass-roots political mobilization and collective action; democracy demands meaningful participation in decision making structures; and sustainability is ensured when future generations have access to the social and material conditions, at least at the same level as the present generation [94,95]. Utopian principles allow us to understand whether we are moving in the right direction, as well as the opportunity to determine how to increase the capacity for transformation towards our desired direction $[96,97]$.

'Real Utopian' approaches consist of strategic alternatives existing within capitalism's niches from which varieties of non-market relations, egalitarian participation, democratic governance and collective action can take hold. Contemporary examples include Wikipedia, where anonymous collaborators contribute to the world's largest encyclopedia without compensation; the Quebec Social Economy, where day-care, elder-care and social housing services exist to meet community needs after deliberation through democratically elected councils; and Universal Basic Income (UBI) proposals that give every legal citizen income sufficient to live above the poverty line without any requirements related to work. Wright argues these strategies can be considered a broad socialist challenge to capitalism [97].

Under this framework, socialist inspired alternatives to capitalism, which adhere to Wright's three strategic 'logics of transformation', are shown in Table 1 below. 'Ruptural' transformations occur through a sharp break with existing institutions and social structures, 'interstitial' transformations build new modes of social empowerment in capitalist society's niches and peripheries, where they often do not seem to present an immediate threat to prevailing power structures, and 'symbiotic' pathways deepen and extend institutional forms of social empowerment that involve the state and civil society simultaneously, whilst solving practical challenges aligned with the interests of the powerful. Where 'ruptural' transformations reflect dramatic revolutionary coups, 'interstitial' and 'symbiotic' 
pathways facilitate growth that remains unmolested by powerful actors and thus, opportunities to successfully grow for the benefit of those who have produced them [94].

Table 1. Three Strategic Transformation Logics derived from [98].

\begin{tabular}{cccccc}
\hline Transformation & $\begin{array}{c}\text { Political } \\
\text { Tradition }\end{array}$ & $\begin{array}{c}\text { Collective } \\
\text { Actors }\end{array}$ & $\begin{array}{c}\text { Relationship } \\
\text { to the State }\end{array}$ & $\begin{array}{c}\text { Relationship } \\
\text { to the } \\
\text { Powerful }\end{array}$ & $\begin{array}{c}\text { Metaphors of } \\
\text { Success }\end{array}$ \\
\hline Ruptural & $\begin{array}{c}\text { Revolutionary } \\
\text { socialist/ } \\
\text { Communist }\end{array}$ & $\begin{array}{c}\text { Class-aligned } \\
\text { political } \\
\text { alliances }\end{array}$ & Attack the state & Confrontational & War (victories) \\
Interstitial & Anarchist & $\begin{array}{c}\text { Self-organized } \\
\text { groups and } \\
\text { social } \\
\text { movements }\end{array}$ & $\begin{array}{c}\text { Build } \\
\text { alternatives } \\
\text { outside of the } \\
\text { state }\end{array}$ & $\begin{array}{c}\text { Exclusive } \\
\text { engagement } \\
\text { with alternative } \\
\text { social relations }\end{array}$ & $\begin{array}{c}\text { Competition } \\
\text { for resources }\end{array}$ \\
\hline $\begin{array}{c}\text { Symbiotic } \\
\text { Metamorphosis }\end{array}$ & Social & $\begin{array}{c}\text { Coalitions of } \\
\text { social forces } \\
\text { and labor }\end{array}$ & $\begin{array}{c}\text { Use the state: } \\
\text { struggle on the } \\
\text { terrain of the } \\
\text { state }\end{array}$ & $\begin{array}{c}\text { Collaborate } \\
\text { with the } \\
\text { bourgeoisie }\end{array}$ & $\begin{array}{c}\text { Evolutionary } \\
\text { adaptations }\end{array}$ \\
\hline
\end{tabular}

Rather than defined steps, utopian thinking encourages mechanisms that facilitate a move toward the desired direction, spurred on by incremental everyday actions that allow for adaptation, improvisation, and amendment [94,99]. In this study, we draw on Wright's (2013) 'Real Utopias' framework for (1) methodological guidance in developing and assessing the viability of desired pathways with small-scale fishers, and (2) to analyze and evaluate the pathways against the moral principles of equality, democracy and sustainability.

\subsection{Lambert's Bay Case}

Lambert's Bay is situated along South Africa's Cape coast (Figure 1) and remains a prominent fishing community due to the variety of commercially viable species including Snoek, Southern Mullet (Liza richardsonnii), Cape Bream (Pachymetopon blochii), White Steenbras (Lithognathus lithognathus), Galjoen (Dichitius capenis) and Dusky Kob (Argyrosomus japonicas) [13]. Artisanal fishers of Lambert's Bay mostly belong to the population group designated as Colored, (the South African state's racial stratification recognizes four racial classifications: African/Black, Indian/Asian, Colored and White. This reflects the racial stratification of colonial South Africa, allowing the state to marginalize those designated as Black, Indian and Colored. The State has continued with these classifications in order to redress past injustices perpetrated during colonialism and continued under Apartheid) [99], speak Afrikaans, and make up 74.53\% of the town's population. Lambert's Bay, as nearly all South African towns, remains geographically split along Apartheid's historic racial zoning, with the White population living in the town, and the Colored and Black populations in the surrounding lower income areas. Overall, $76.5 \%$ of households are without home internet access, and only $26.4 \%$ of adults had graduated from secondary school [100].

Inconsistent application of fisher rights have led to divisions where ITQs have created differences in income, asset ownership and household food security [101] amongst artisanal fishers. Further, ITQs were allocated to a more educated elite as well as those in faraway metropoles-neither of whom had any historic dependence on marine resource harvesting. Artisanal fishers excluded from rights allocations thus had their livelihoods effectively criminalized [102]. 


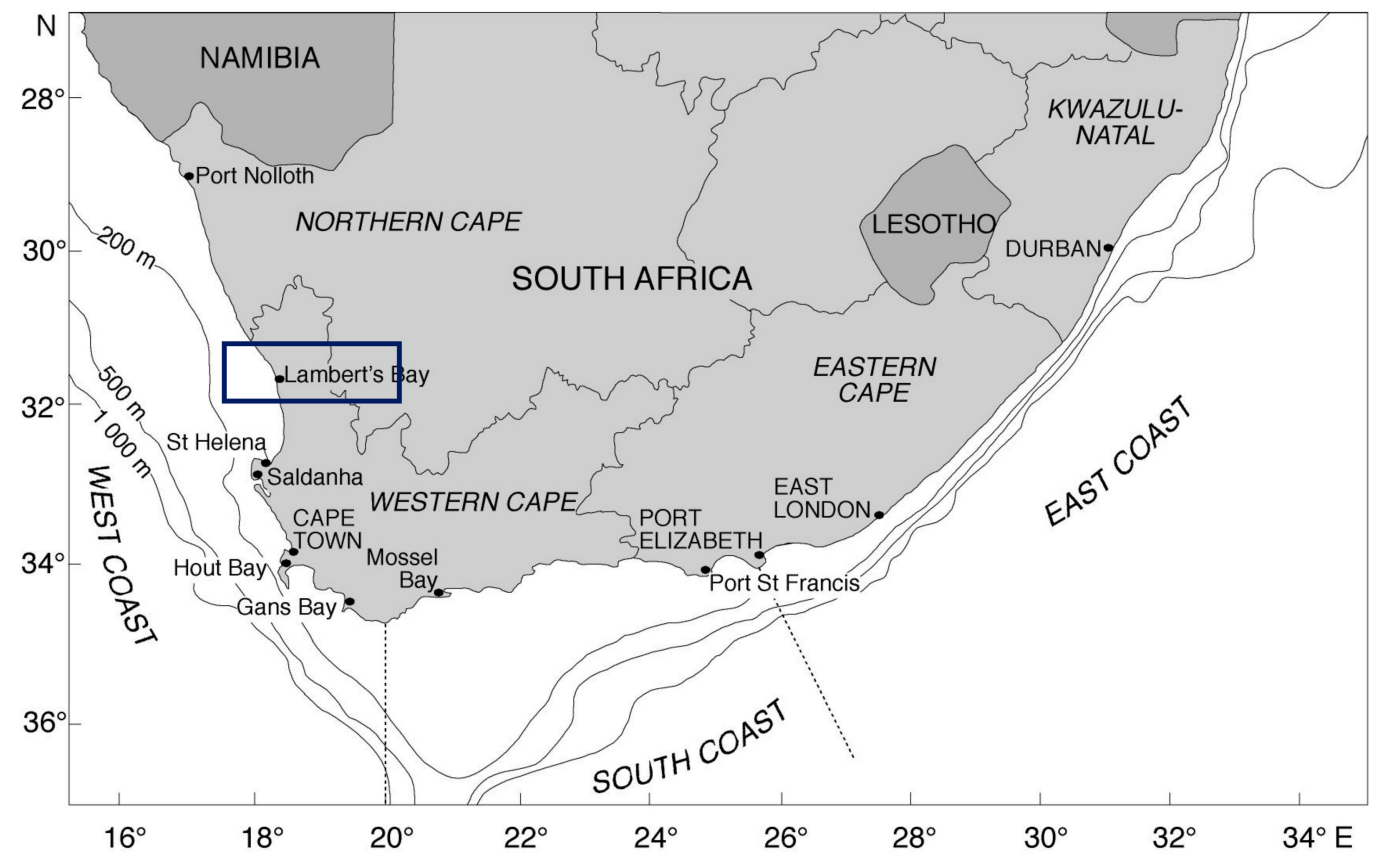

Figure 1. Lambert's Bay, South Africa (adapted from [103]).

\section{Materials and Methods}

This present study represents the ongoing research amongst the Lambert's Bay fisher community since 2013. Initial investigations focused on establishing household livelihood profiles of Lambert's Bay small-scale fisher families, exploring the role of quota allocations and the implications for small-scale fisher community dynamics [102]. Subsequent research (September 2014-March 2015) focused on co-design work conducted with support of the JUSTMAR Network (Global Marine Governance Network-Co-constructing a Sustainable Fisheries Future), financed both by the International Social Science Council, ISSC, and the Swedish Research Council/Swedish Research Links (VR/SR). JUSTMAR researchers delineated [104] fisher transformation pathways from Poland, Chile, South Africa and Vietnam. Whereas the JUSTMAR research mapped historical and current problems in the small-scale fisheries of the respective countries, as well as identifying possible pathways, the purpose of this workshop was to deepen the co-design of ICTs, where ICTs were increasingly seen as potential transformation pathways based on the future visioning of South African small-scale fishers. The intention was, moreover, not to envision and realize the 'ideal' but to work towards and facilitate conditions more in line with desired futures.

We held an evaluation and planning session in a community conferencing facility in Lambert's Bay, South Africa. We recruited participants through purposive sampling selection of Lambert's Bay fishers actively participating on the Abalobi platform, with a particular focus on skipper-boat owners, who were approached through telephone without the assistance of state agents or fisher associations. The focus on skipper-boat owners meant most participants were male and represented a relatively privileged group within the community both in terms of ownership over means of production and with regards to their association with the Abalobi project. While this represented a limitation to understanding power between diverse actors within the Lambert's Bay fishing community, our focus was primarily to explore the power dynamics between this particular group of fishers, middlemen and the State.

Though a larger number of fishers were expected to attend the workshop, some could not attend because the workshop coincided with particularly good fishing days. In total, six skipper-boat owners, 1 skipper, 1 fisherwoman and a local domestic violence counsellor participated. Our workshop was facilitated by two Abalobi project directors and four University researchers, of which two came from the University of Cape Town, South Africa and the remainder from Södertörn University, 
Sweden, and primarily affiliated with JUSTMAR. All subjects gave their informed consent for inclusion before they participated in the workshop. The study was conducted in accordance with the Declaration of Helsinki, and the protocol was approved by the Ethics Committee of the University of Cape Town, South Africa.

Informed by the knowledge from prior JUSTMAR work, the researchers, fishers and NPO staff agreed in advance to exploring themes related to how ICTs can play a role in value chain participation, the associated challenges, opportunities and related governance concerns. Our format followed a mixed approach of plenary sessions and small group work where problems were presented with open discussion about solutions through presentations from fishers [105]. Our workshop's introduction highlighted how TURFS are widely seen as pathways for sustainable small-scale futures prominent in the fisheries of Vietnam and Chile. Our purpose was, thus, for South African small-scale fisheries to develop their own pathways, bearing in mind conflict, power and research constraints with a view to ultimately develop and enact selected ICT-based transformation strategies.

Though Lambert's Bay small-scale fishers primarily speak Afrikaans, our workshop was conducted in English, with translation assistance through a long term Lambert's Bay community member who was also an initiator of the Abalobi project. We conducted self-reporting strength and weakness exercises in order to understand a fisher's perceptions of challenges and opportunities within their practice. We subsequently explored future strategies, referencing how in Chile, fisherwomen developed a book as a means to raise their profile.

After mapping fisher problems in detail, participants were tasked with drawing up transformation pathways that would enable them to meet their value chain, upgrading goals through the ICT platform. This also required elucidating the roles and responsibilities of the various stakeholders towards fulfilling these opportunities, ensuring the viability, desirability and sustainability of a tangible action plan. In addition, our workshop sought to identify unintended consequences on both participating fishers and other actors. We took detailed field notes during the workshop and drew up fisher pathways on white boards in order to facilitate agreement on common issues. The outputs generated through the sessions directly informed the design of the Abalobi 'Marketplace' ICT module, which we subsequently piloted in two fishing communities.

Our data were coded for dominant themes continuously and iteratively $[106,107]$ over a period of months, primarily guided by Real Utopian and Value Chain frameworks. Some constraints included the reality that fishers in different roles were not used to discussing issues openly together, for instance, crew and skippers, women amongst the men, and youth in front of their elders. The low scientific literacy levels may have led fishers to easily defer to those perceived to hold greater power or knowledge such as NPO staff and the researchers. However, the workshop approach facilitated in-depth discussion because of the relatively loose structure that left room for participants to grow in confidence.

\section{Discussion}

Through the workshop, fishers identified multiple short and longer term strategies to pursue, using the Abalobi ICT platform as presented in Table 2. It was apparent fishers connected the success of the Abalobi platform with the future subscription of all fishers in the Lambert's Bay community. Association with the Abalobi project represented a relatively privileged position amongst local fishers. This was evidenced through discussions on recruitment, where fishers involved with Abalobi saw themselves as singularly committed to fisher issues, and setting the terms of engagement for other fishers to join the platform: 
Table 2. Fisher Strategy Workshop Outputs.

\begin{tabular}{ll}
\hline \multicolumn{1}{c}{ Workshop Output: Fisher Strategies } \\
\hline a. & Recruit all fishers to the Abalobi ICT platform \\
b. Eliminate middleman \\
c. Use indigenous knowledge \\
d. Organize independently \\
e. Establish accident fund \\
f. Begin discussions with banks \\
g. Determine a salary structure \\
h. Keep commercial fleets out of inshore \\
i. Run local festivals and markets around fish \\
j. Use case studies to learn from other fishers \\
\hline
\end{tabular}

"... our fishers are also divided, the clique who are here [working with Abalobi] is [sic] very committed ... but when we go to sea, there are no enemies." (FP1, young skipper, male, 03/10/2017)

"We want every fisher to be a part of Abalobi under our terms ... if you don't want to listen to us then you must go." (FG1, skipper group, 03/10/2017)

Fishers further expressed the desire for the ICT platform to resolve issues related to eliminating the middleman in their value chains and developing local markets, participating effectively in fisheries management by leveraging indigenous knowledge, increased fisher self-organization, the establishment of an accident insurance fund, formal recognition by the banks, protecting their inshore fishing areas from commercial fleets, and learning from case studies in different country contexts.

The overarching challenge to the Lambert's Bay fishers was the ways in which their participation in value chains reinforced asymmetric power relations from which small-scale fishers derived little benefit. With fishers unable to renegotiate their terms of inclusion [39], deriving better returns from their value chains through strengthened bargaining positions thus guided our discussions around transformation pathways. Specifically, small-scale fishers identified the adverse nature of patron-client relationships as a key hindrance to receiving greater value for their harvests. In both their low value Snoek and high value Lobster chains, small-scale fishers derived the least benefit $[13,39,108]$.

"... the main point is marketing, that's our biggest weakness in our fishing sector. With marketing, some middleman take our catch and go to Cape Town and spend its money there. And as I told you this type of period they come and let [sic] us some money and we must sign our debt by them [sic] and so it go." (FG1, skipper group, 03/10/2017)

"We are not organized, there is no organization to organize us. There is a caretaker who must speak with government for us ... but the caretaker is also the marketing 'ou se boy' [sic]. There are no person to talk for us." (FG1, skipper group, 03/10/2017)

Although patron-client relationships have been noted to mediate fisher access in small-scale fisheries worldwide and though much derided, research is increasingly recognizing the ways in which middlemen in dense fisher networks may hold close kinship relationships with fishers and provide the operational capital for fishers to mobilize for the start of a new season [109-114]. Whilst this trend is observed across small-scale fisheries globally, fishers felt the South African state had effectively absolved themselves of the responsibility of supporting fisher marketing functions. While 'caretaker-marketers', as they are known in South Africa, provide loans to small-scale fishers, they also act with an impunity that may be detrimental to the economic welfare of fishers [39].

"Our relationship with the government, there are no relationship - the only relationship is with the caretaker and the caretaker take care of all of us." (FG1, skipper group, 03/10/2017) 
Adversely included small-scale fisher value chain actors have overcome exploitation through the rise of local food movements that shorten small-scale fisher value chains by sourcing directly from fishers, bypassing the middleman and encouraging fisher post-harvest processing $[48,49,115,116]$. Despite the importance of effective governance to small-scale fisher value chains [13,117-120], small-scale fishers further bemoaned the lack of effective co-management structures through which they could exercise influence on policy.

Together with the Abalobi NPO, small-scale fishers synthesized three priority transformation pathways to pursue over the five-year period. First, fishers desired to strengthen independent fisher organizations to address the government's delay in implementing state supported fisher cooperatives and allocating their respective fishing rights. This was primarily in response to the delays in the implementation of the Small-scale Fisher Policy. Second, small-scale fishers desired to develop an alternative value chain that allowed fishers to participate more equitably by overcoming the asymmetric power relationships with other actors. Thirdly, fishers desired to collect fishing trip data through the Abalobi ICT platform in order to demonstrate their largely unrecognized contribution to South Africa's fishery sector, whilst also leveraging the data to advocate for greater participation in fisheries co-management.

"Abalobi gave us a much more way [sic] of thinking with what we are doing because now we can start monitoring our fishing, everything like that, and get it in the database ... that is one of our strengths." (skipper, male, 03/10/2017)

"The indigenous knowledge is also a great strength because now we can use our knowledge, indigenous knowledge, somehow to be a part of Abalobi and there are some hope there ... that's our strength in the room, we have a lot of knowledge here by us [sic]." (FG1, skipper group, 03/10/2017)

In order to support them more effectively, we examined these strategies through ICT and 'Real Utopian' lenses, relating them to other fisheries contexts in order to connect these actions of local fishers to global processes of anti-capitalist social change in small-scale fisheries.

\section{ICTs, Real Utopias and Social Change in Small-Scale Fisheries}

\subsection{Addressing State Incapacity}

Wright's definition of equality involves living a 'flourishing life' supported by grass-roots political mobilization and collective action [94]. Yet Lambert's Bay fishers endured a period of waiting due to State incapacity that only exacerbated their vulnerability from inequitable rights allocations. For instance, State-run fisher organization remained a laborious process, hamstrung by the necessity to ensure integrity of the verification and appeals process. Despite devolving verification to fisher communities, the extended delays and mistakes from the premature roll out of earlier years misallocated resources, and the subsequent delays continued to deny fishers access to state resources [7]. In this vacancy, fishers established formal and informal cooperatives to pursue alternatives to the state's incessant delays as a strategy of overcoming State incapacity

Fishers understood the potential of leveraging the Abalobi ICT platform towards greater independent mobilization, particularly in light of the perception the state had left them to the mercy of unscrupulous marketers. While the workshop represented one such arena to facilitate the actions of local fishers towards collective action, Abalobi-affiliated fishers further frequently met to resolve value chain challenges such as at whose house post-harvest processing should occur, how to compensate fish cleaners, as well as resolving perceptions of favoritism between fishers. In addition, the delays of the small-scale fisher policy implementation of community cooperatives left room for the growth of independent fisher organization, with the Abalobi platform operating as a de facto fisher cooperative, looking after the economic and political interests of small-scale fishers.

The wait of small-scale fishers for a policy that recognized them drew parallels with the wait for housing in South African urban spaces. In the urban space, this waiting shaped a politics of finding 
solutions in the grey spaces of informality and illegality [31]. Here, housing activists had sought sustainable alternatives to the hegemonic state discourse and housing policy towards inclusiveness for the homeless. While in the fisheries sector, the development of the policy marked citizens as legitimate wards of the state, their precarious existence throughout the policy's development and over the long term also required subversion of fisher regulations by poaching to support their livelihoods. Though South African state fisheries governance had scheduled completion of the verification process in 2020, this waiting had led fishers to start their own cooperatives.

In the urban housing literature, capacity was built through mobilizing local communities and demonstrating results through an alternative housing model [32], which highlights the importance for fishers of the viability of Abalobi's alternative value chain model. For small-scale fisher transformation pathways to embody equality, they will need to deliver on their promises promptly, where the perennial experiences of waiting result in exacerbated livelihood vulnerability.

The Abalobi ICT project facilitates collective action and mobilization by congregating small-scale fisher action toward value chain upgrading. Apart from the above 'co-design' workshops, Abalobiaffiliated small-scale fishers share marketplace information over 'Whatsapp' skipper groups, where this sort of collaborative skipper action is rare in Lambert's Bay. The Abalobi 'Fisher' module that captures logbook data from participating small-scale fisher trips further has the potential to be used for political mobilization through collective analysis of the data. Where development is understood as the increase in power parity [71], accurate small-scale fisheries data facilitates a pathway for fishers to leverage this important data towards gaining greater influence in fisheries management.

Collective action can enhance equality through the joint effort of pursuing political goals [91]. The Abalobi platform offers a space through which continued fisher cooperation can be leveraged towards achieving their political goals. A study in Nepal, linking ICT to fostering collective action, highlights the facilitative role of ICTs in generating and maintaining trust, acceptance, and alignment essential to cooperation through improved transparency and participation-where this collective action ultimately facilitates the expansion of individual freedoms [119].

\subsection{Linking Actions of Local Fishers to Socio-Economic Outcomes}

Post-Apartheid South Africa is marked by an increase in social inequality, particularly in the context of neo-liberal macroeconomic policies. Contesting neoliberalism has occurred across multiple civil society groups- - here, we adopt understandings from South Africa's housing movement that draws important parallels for fisher struggles. Where Wright defines 'democracy' as meaningful participation, lessons from South African housing social movements highlight the inadequacy of basing democracy on free and fair elections, for example, mistaking institutional instruments with their democratic purpose [120]. The relationship between democracy and socio-economic rights remains complex, where too often liberal democracy is projected to lead to increased socio-economic rights, yet macroeconomic inequality has shown this to not be the case [29].

Participation processes need to result in real change. This includes more direct lines of accountability from local outcomes to local decision makers, as well as increased spaces from informal discussion concerning management issues [121]. These transformation pathways must, therefore, embody more than participation and transparency to also include socio-economic redress and gain in order to satisfy more comprehensive goals of democracy, especially in light of the ways in which democracy has not provided fishers with transformative socio-economic possibilities in post-Apartheid South Africa [8]. Though fisher rights are enshrined in a much-lauded Constitution, our experience in South African fisheries, as well as the literature, show they remain impoverished and marginalized with a significant schism between democracy and socio-economic redress.

One strategy to directly link democratic processes to socio-economic outcomes involved the Abalobi ICT platform facilitating local festivals and markets around their fish and developing a Restaurant Supported Fishery (RSF). While local fish markets are ubiquitous in fisheries globally, Apartheid laws denied small-scale fishers the opportunity to develop their own, creating highly centralized value 
chains under the control of a few large companies. Subsequent to the workshop, we thus established a small-scale fisher processing facility using the rudimentary facilities of a participating skipper. This processing facility conducted all the post-harvest fish processing of the new Abalobi-facilitated value chain, with fishers utilizing their traditional gutting methods and expertise. This decentralization of processing functions represented an example of increasing democratic freedoms with positive implications for socio-economic redress, as fishers were able to charge higher prices for their fish. Further, by facilitating small-scale fisher control of processing, fishers had the ability to bring to bear their local knowledge and cultural traditions in the post-harvest process. This further serves as a platform for fishers to leverage increased control of the post-harvesting process towards establishing independent local fish markets.

Transformative pathways linking democratic principles with real socio-economic benefits have been implemented in global fisher contexts, where in 2014, Scottish government reforms of Fixed Quota Allocations posited future scenarios for addressing moral economy issues in their fisheries. The Scottish government considered wellbeing above market precepts through six proposals: reducing fees on quota leases, facilitating youth entry in to fisheries, restricting quota allocation to active fishers, keeping quotas under Scottish ownership, keeping quotas within coastal communities, and supporting the traditions and practices of artisanal fishers [122]. These reforms can further serve as learnings and possibilities for South African fisher democratic ideals that place social and distributional objectives on equal importance as economic ones whilst recognizing coastal fishing communities, small-scale fisheries and communal traditions.

In considering transformation pathways, it is critical that small-scale fishers reflect on whether their existing practices contribute to economic welfare through operating in a democratic manner, allowing access and distributing that access justly. This is particularly important where communities have historically seen fractures brought on by the inequitable distribution of fishing rights. Fishers and the Abalobi staff will thus need to continuously reflect on how decisions are made and their implications-locating the processing facility in a particular skipper's home, for instance, resulted in perceptions of favoritism (pers. comm) requiring careful conflict management. Successful small-scale fisher-run processing facilities can serve as a rallying call for public support of their transformation pathways that demonstrate how fishers serve the public good by offering value and employment out of a publicly-owned resource, whilst also highlighting self-directed and self-supported fisher initiatives [123].

Case studies of Canadian Yukatat and Metlakatla fishing villages show how artisanal fisheries can be rebuilt on local and traditional knowledge, as well as incumbent subsistence technologies that open new opportunities within the existing neoliberal framework that retain local cultural traditions and support artisanal fisher identities. One of these strategies involves transferal of fish processing plant ownership rights to artisanal fishers who can then lease or operate the plant [123], which requires governments to provide subsidies towards value, adding capacity amongst artisanal fishers. These reforms also point to the importance of place-based identity and occupational stability, which South African fishers have struggled for through adhering to ideals of democracy and equality. Nonetheless, whether democracy and equality are conceptualized apart or highly integrated, fisheries governance needs to prioritize how fishers conceptualize traditional, moral and economic understandings of these ideals [124].

For small-scale fishers, democracy extends particularly to greater participation in the decisions that affect their livelihoods, such as state fisheries management decisions and policy prescriptions. Yet, democracy that has no direct benefit to the socio-economic improvement of livelihoods is inadequate. For South Africans and small-scale fishers for our purposes, the new democratic dispensation in 1994 and subsequent fisheries reform yielded no direct socio-economic benefit for small-scale fisheries. Rather, small-scale fishers remained marginalized and excluded from fisheries access under the neoliberalism-guided Marine Living Resource Act of 1998. 
ICTs have the potential to facilitate democratic practice and improved socio-economic outcomes. By understanding development as increased economic productivity and power parity [71], ICT interventions should increasingly strive to pursue a welfare and fulfilment agenda beyond issues of access and resources [70]. Significantly, Abalobi's Marketplace platform offered fishers the opportunity to shorten their value chains by bypassing middlemen and selling directly to restaurants whilst receiving a higher price. Direct marketing programs in small-scale fisheries have shown to facilitate increased economic returns whilst increasing power parity between small-scale fishers and other value chain actors $[46,49,115]$. As demands on democracy are extended to meaningful participation in decision making, the urgency of concomitant economic benefits remain essential, particularly for fishers experiencing continued and historical marginalization.

\subsection{Scaling Local Fisher Institutions}

Reference [94] considers sustainability related to securing consumption of resources, as well as environmental conditions for future generations, at least at the same level as present, with scalable utopian institutions key to a sustainable future. Lessons from the alternative food movement highlight the importance of considering how transformation pathways can scale, as a key component of ensuring this sustainability. This involves exploring two related issues: the first concerns the capability for potential merging of multiple transformation pathways to facilitate innovative spillover and cross-fertilization-where one pathway may yield learnings for the growth of others. The second concerns the potential for transformation pathways to facilitate more interstitial space in which new pathways can grow, ultimately creating 'safe havens' of empowerment within existing institutional structures [125].

Fisher transformation pathways, such as Abalobi's Restaurant Supported Fishery value chain, needs to be flexible enough to navigate through the ways in which fishers will face resistance while leveraging the options to exploit resources within incumbent value chains. Transformation pathways begin with the risk of remaining just reactive alternatives to the mainstream, owing their dynamism to the 'oppositional status' created by the hegemonic neoliberal regime [126]. Fishers thus need to be careful to establish their transformation pathways beyond oppositional entities towards developing new governance modes based upon public priorities and fisher sovereignty [125].

Fisher desires to use the platform to engage with distant fishing communities was an example in which the ICT platform was leveraged to scale towards greater fisher collective action. Further, the 'Marketplace' module was piloted in two communities on opposite coasts of the Western Province of South Africa. Fishers used this collaboration to plan to offer diverse species on their future local markets, because certain species were exclusive to particular fishing areas. The increasing roll-out of the Abalobi platform across multiple communities, thus facilitates scaling of the platform with great potential for increasing the opportunities for the convergence of local movements, initiatives, ideas, and sustainable fishing practices.

In the alternative food movement, the twin crises of consumption and production and their impact on the urban consumer led to conditions that opened up more voids and spaces for new post-neoliberal institutional alternatives [126]. However, this conceptualization privileges the crisis of a wealthier consumer as the catalyst for change over that of the marginalized small producer who remains in a perennial state of vulnerability. Nonetheless, it is a useful way to understand how transformation pathways might develop; in South African small-scale fisheries the crisis amongst small-scale fishers has precipitated the development of alternative pathways more than a crisis of actors further along the value chain.

Convergence of food movements had been the key driver of food movements becoming major socio-political avenues for embedding and facilitating the transition to a post-neoliberal economy [126]. To leverage convergence, small-scale fishers of Lambert's Bay will need to develop closer relationships with other fisher communities and activities, a task made harder by the destructive role of ITQs. 
However, in seeking convergence, fisher movements will need to be wary of appropriation and co-option, while remaining flexible enough to accommodate potentials for convergence $[126,127]$

Even where ICT projects are initially successful, when donor and state support is reduced or terminated, projects are prone to failure as demonstrated through a large study in India [71]. ICT- supported alternative pathways thus remain fundamentally tethered to the existence and scalability of the supporting ICT platform. Lessons from organizing within the social food movements show how convergence with other social movements may help solve the intractable existential crises of ICT projects whilst facilitating the maintenance of utopian alternatives [95,128]. ICT projects are commonly initiated by external partners with donor funding rather than by community members where the intervention occurs, reflecting power asymmetries related to resources. Consequently, money allotted to ICT projects seldom includes scope for exploring avenues for convergence with other ICT and analogue projects, which is crucial for sustainability, as lessons from alternative food movements indicate. Thus, explicitly pursuing areas of convergence with initiatives with similar aims might enhance the sustainability of utopian alternatives and ICT projects themselves.

\section{Limitations}

For small-scale fishers, individual access and subsequent use of marine resources is embedded in social relationships where neither 'property' nor 'rights' bear meaning other than as conditions imposed by external authorities [112], and where fishing practices continue to contribute to the unique cultural landscape of Lambert's Bay [13]. Thus, understanding their character and dynamics remains imperative for uncovering what matters to and for fishers, towards facilitating collective action [12], and the meanings of equality, democracy and sustainability as conceptualized by fishers.

These exchange relationships embedded in social and political conditions also determine the extent to which fishers capture a fair share of economic value of their resources which highlights the role of these relationships in disempowerment, exploitation and power inequalities [127]. Whilst emphasizing customary practices and traditions is essential for fisher transformation strategies, these practices may also represent and enable a tyranny of collective self-interest that encourage nepotism, ethnocentricity and gender inequalities-ultimately compromising the principles of transformative fisher pathways [128].

Though collecting small-scale fisheries data is critical to small-scale fisheries across the socio-ecological spectrum, it is often collected by non-state actors-raising questions of who generates the data, owns it, and has the skills and resources to analyze and use it. Power asymmetries exist inherently when non-state actors intervene in small-scale fisher communities. It is imperative ICT projects mitigate the ways in which power asymmetries within their projects undermine their stated goals. Small-scale fishers should not remain mere passive producers of data [69].

With co-design approaches at the forefront of greater stakeholder inclusion in ICT projects, project initiators must reflect on and actively mitigate the data inequalities present in their projects. This requires embedding participants in processes along the data chain beyond data generation, recognizing there are often different roles in different phases of ICT $[129,130]$. In pursuing greater power parity through ICT-based value chain upgrading, it would be a critical oversight if the Abalobi project were to neglect the power asymmetries embedded in ICT data chains.

For small-scale fishers, exploring new value chains supported through the Abalobi ICT platform necessarily requires redirecting catches that would ordinarily flow to the incumbent value chain and its associated actors. Where the strength of social networks are important determinants of benefit and credit flows in fisher communities [111,113], severing or even weakening the strength of these relationships may hold dire livelihood consequences, should the sustainability of the ICT-supported value chain be in financial peril.

Finally, Apartheid remains the central determinant of the life opportunities of South Africans from birth to death. The Apartheid government's inequitable distribution of resources remains stubbornly entrenched, affecting where people live, their education and subsequent career prospects, access to 
basic services and dignity. Lambert's Bay small-scale fishers remain marginalized, burdened with significant constraints for opportunities to lead flourishing lives. Directing social change where the trauma of the past continues to define the experiences of small-scale fishers poses complex and uncertain challenges for transformation pathways. It is imperative that fisher interventions remain attuned to this complexity where the real needs of fishers, including dignity, identity and cultural practice are not overlooked in favor of mainstream economic upgrading initiatives.

\section{Conclusions}

Whilst fisher participation is critical to ICT-related transformative small-scale fisheries interventions, it is imperative these pathways embody enhanced notions of democracy, equality and institutional and environmental sustainability. Through alternative small-scale fisher value chains, ICTs offered real material benefit for fishers whilst also facilitating democratic practices by leveraging fisher data towards increased power parity in management decisions. Early successes may help build confidence among fishers, authorities and market actors. This may be important to engender recognition that alternative pathways are indeed able to deliver on their promises. Lastly, sustaining transformative institutions requires ICTs to explore areas of convergence with other local fisher communities, particularly where fisher participation in transformation pathways necessitates a weakening of their long-held relationships with local stakeholders.

Author Contributions: S.R., F.S. and G.L.G.F. conceived and designed the project. F.S., G.L.G.F. and T.T.N. performed the analysis. T.T.N. wrote the paper with input from all authors. All authors have read and agreed to the published version of the manuscript.

Funding: This research was supported by the JUSTMAR Network (Global Marine Governance Network-Co-constructing a Sustainable Fisheries Future), financed both by the International Social Science Council, ISSC, and the Swedish Research Council/Swedish Research Links (VR/SR); and the APC was funded by the University of Cape Town, South Africa.

Conflicts of Interest: The authors declare no conflict of interest. The funders had no role in the design of the study; in the collection, analyses, or interpretation of data; in the writing of the manuscript, or in the decision to publish the results.

\section{References}

1. Béné, C.; Arthur, R.; Norbury, H.; Allison, E.H.; Beveridge, M.; Bush, S.; Campling, L.; Leschen, W.; Little, D.; Squires, D.; et al. Contribution of Fisheries and Aquaculture to Food Security and Poverty Reduction: Assessing the Current Evidence. World Dev. 2016, 79, 177-196. [CrossRef]

2. Grafeld, S.; Oleson, K.L.L.; Teneva, L.; Kittinger, J.N. Follow that fish: Uncovering the hidden blue economy in coral reef fisheries. PLoS ONE 2017, 12, e0182104. [CrossRef] [PubMed]

3. Bentley, N.; Stokes, K. Contrasting Paradigms for Fisheries Management Decision Making: How Well Do They Serve Data-Poor Fisheries? Mar. Coast. Fish. Dyn. Manag. Ecosyst. Sci. 2009, 1, 391-401. [CrossRef]

4. Geromont, H.F.; Butterworth, D.S. Generic management procedures for data-poor fisheries: Forecasting with few data. ICES J. Mar. Sci. 2015, 72, 251-261. [CrossRef]

5. Jeffers, V.F.; Humber, F.; Nohasiarivelo, T.; Botosoamananto, R.; Anderson, L.G. Trialling the use of smartphones as a tool to address gaps in small-scale fisheries catch data in southwest Madagascar. Mar. Policy 2019, 99, 267-274. [CrossRef]

6. Van Sittert, L.; Branch, G.; Hauck, M.; Sowman, M. Benchmarking the first decade of post-apartheid fisheries reform in South Africa. Mar. Policy 2006, 30, 96-110. [CrossRef]

7. Sowman, M. Subsistence and small-scale fisheries in South Africa: A ten-year review. Mar. Policy 2006, 30, 60-73. [CrossRef]

8. Isaacs, M. Small-scale fisheries reform: Expectations, hopes and dreams of "a better life for all". Mar. Policy 2006, 30, 51-59. [CrossRef]

9. Belhabib, D.; Sumaila, U.R.; Le Billon, P. The fisheries of Africa: Exploitation, policy, and maritime security trends. Mar. Policy 2019, 101, 80-92. [CrossRef] 
10. Naranjo-Madrigal, H.; van Putten, I. The link between risk taking, fish catches, and social standing: Untangling a complex cultural landscape. Mar. Policy 2018, 100, 173-182. [CrossRef]

11. Antonova, A.S.; Rieser, A. Curating collapse: Performing maritime cultural heritage in Iceland's museums and tours. Marit. Stud. 2019, 18, 103-114. [CrossRef]

12. Henrich, J.; Boyd, R.; Bowles, S.; Camerer, C.; Fehr, E.; Gintis, H.; Mcelreath, R.; Alvard, M.; Barr, A.; Ensminger, J.; et al. "Economic man" in cross-cultural perspective: Behavioral experiments in 15 small-scale societies. Behav. Brain Sci. 2005, 28, 795-855. [CrossRef] [PubMed]

13. Isaacs, M. Small-scale fisheries governance and understanding the snoek (Thyrsites atun) supply chain in the ocean view fishing community, Western Cape, South Africa. Ecol. Soc. 2013, 18, 17-31. [CrossRef]

14. Eusebio, J.J. A Research Framework on Value-Chain Analysis in Small Scale Fisheries; Indiana University: Bloomington, IN, USA, 2004; pp. 1-27.

15. Jensen, R. The Digital Provide: Information (Technology), Market Performance, and Welfare in the South Indian Fisheries Sector. Q. J. Econ. 2007, 122, 879-924. [CrossRef]

16. Omar, S.; Chhachhar, A. A review on the roles of ICT tools towards the development of fishermen. J. Basic Appl. Sci. Res. 2012, 2, 9905-9911.

17. Srinivasan, J.; Burrell, J. Revisiting the Fishers of Kerala, India; Association for Computing Machinery: New York, NY, USA, 2013.

18. Aker, J.C.; Ghosh, I.; Burrell, J. The promise (and pitfalls) of ICT for agriculture initiatives. Agric. Econ. 2016, 47, 35-48. [CrossRef]

19. Riisgaard, L.; Bolwig, S.; Ponte, S.; Halberg, N.; Matose, F. Integrating Poverty and Environmental Concerns into Value-Chain Analysis: A Strategic Framework and Practical Guide. Dev. Policy Rev. 2010, 28, 195-216. [CrossRef]

20. Bush, S.R.; Oosterveer, P.; Bailey, M.; Mol, A.P.J. Sustainability governance of chains and networks: A review and future outlook. J. Clean. Prod. 2015, 107, 8-19. [CrossRef]

21. Bolwig, S.; Ponte, S.; Toit, A. Integrating Poverty and Environmental Concerns into Value-Chain Analysis: A Conceptual Framework. Dev. Policy Rev. 2010, 28, 173-194. [CrossRef]

22. Baudoin, M.-A.; Henly-Shepard, S.; Fernando, N.; Sitati, A.; Zommers, Z. From Top-Down to "Community-Centric" Approaches to Early Warning Systems: Exploring Pathways to Improve Disaster Risk Reduction Through Community Participation. Int. J. Disaster Risk Sci. 2016, 7, 163-174. [CrossRef]

23. Bremer, S.; Haque, M.M.; Haugen, A.S.; Kaiser, M. Inclusive governance of aquaculture value-chains: Co-producing sustainability standards for Bangladeshi shrimp and prawns. Ocean Coast. Manag. 2016, 131, 13-24. [CrossRef]

24. United Nations Development Programme. Sustainable Development Goals|UNDP; United Nations: New York, NY, USA, 2015.

25. Ntona, M.; Morgera, E. Connecting SDG 14 with the other Sustainable Development Goals through marine spatial planning. Mar. Policy 2018, 93, 214-222. [CrossRef]

26. Isaacs, M. Individual transferable quotas, poverty alleviation and challenges for small-country fisheries policy in South Africa. MAST 2011, 10, 63-84.

27. Isaacs, M.; Witbooi, E. Fisheries crime, human rights and small-scale fisheries in South Africa: A case of bigger fish to fry. Mar. Policy 2019, 105, 158-168. [CrossRef]

28. Sowman, M.; Cardoso, P.; Fielding, P.; Hauck, M.; Raemaekers, S.; Sunde, J.; Schultz, O. Human Dimensions of Small-Scale Fisheries in the BCLME Region: An Overview Prepared by Prepared for Benguela Current Commission (BCC) and Food and Agricultural Organisation (FAO); Food and Agricultural Organisation of the United Nations: Rome, Italy, 2011.

29. Stokke, K.; Oldfield, S. Social Movements, Socio-economic Rights and Substantial Democratisation in South Africa. In Politicising Democracy; Harriss, J., Stokke, K., Törnquist, O., Eds.; Palgrave Macmillan: London, UK, 2005; pp. 127-147.

30. Friedman, S. The More Things Change ... South Africa's Democracy and the Burden of the Past. Soc. Res. Int. Q. 2019, 86, 279-303.

31. Oldfield, S.; Greyling, S. Waiting for the state: A politics of housing in South Africa. Environ. Plan. A 2015, 47, 1100-1112. [CrossRef]

32. Millstein, M.; Oldfield, S.; Stokke, K. uTshani BuyaKhuluma-The Grass Speaks: The political space and capacity of the South African Homeless People's Federation. Geoforum 2003, 34, 457-568. [CrossRef] 
33. Bénit-Gbaffou, C.; Oldfield, S. Accessing the State: Everyday Practices and Politics in the South. J. Asian Afr. Stud. 2011, 46, 445-453. [CrossRef]

34. Isaacs, M. Multi-stakeholder process of co-designing small-scale fisheries policy in South Africa. Reg. Environ. Chang. 2016, 16, 277-288. [CrossRef]

35. Witbooi, E. Subsistence Fishing in South Africa: Implementation of the Marine Living Resources Act. Int. J. Mar. Coast. Law 2002, 17, 431-440.

36. Ponte, S.; Sittert, L. Van The Chimera of redistribution in post-apartheid South Africa: “Black Economic Empowerment" (BEE) in Industrial Fisheries. Afr. Aff. 2007, 106, 437-462. [CrossRef]

37. Sowman, M.; Scott, D.; Green, L.J.F.; Hara, M.M.; Hauck, M.; Kirsten, K.; Paterson, B.; Raemaekers, S.; Jones, K.; Sunde, J.; et al. Shallow waters: Social science research in South Africa's marine environment. Afr. J. Mar. Sci. 2013, 35, 385-402. [CrossRef]

38. Department of Agriculture, Forestry and Fisheries. Policy for the Small Scale Fisheries Sector in South Africa; Department of Agriculture, Forestry, and Fisheries: Cape Town, South African, 2012.

39. Wentink, C.R.; Raemaekers, S.; Bush, S.R. Co-governance and upgrading in the South African small-scale fisheries value chain. Marit. Stud. 2017, 16, 5. [CrossRef]

40. Abalobi. About|ABALOBI. Available online: http://abalobi.info/about/ (accessed on 2 September 2017).

41. Srinivasan, J.; Burrell, J. Revisiting the Fishers of Kerala, India (Working Draft). In Proceedings of the Forthcoming at the International Conference on Information and Communication Technologies and Development, Cape Town, South Africa, 7-10 December 2013; pp. 56-66.

42. Jensen, R. Information, Efficiency and Welfare in Agricultural Markets. In Proceedings of the 27th International Association of Agricultural Economists Conference, Beijing, China, 16-22 August 2009; pp. 1-24.

43. Duncombe, R. Mobile Phones for Agricultural and Rural Development: A Literature Review and Suggestions for Future Research. Eur. J. Dev. Res. 2016, 28, 213-235. [CrossRef]

44. David, S.; Sabiescu, A.G.; Cantoni, L. Co-Design with Communities. A Reflection on the Literature. In Proceedings of the 7th International Development Informatics Association Conference, Lugano, Switzerland, 1-3 November 2013.

45. Smith, R.C.; Bossen, C.; Kanstrup, A.M. Participatory design in an era of participation. CoDesign 2017, 13, 65-69. [CrossRef]

46. Brinson, A.; Lee, M.-Y.; Rountree, B. Direct marketing strategies: The rise of community supported fishery programs. Mar. Policy 2011, 35, 542-548. [CrossRef]

47. Campbell, L.M.; Boucquey, N.N.; Stoll, J.; Coppola, H.; Smith, M.D. From Vegetable Box to Seafood Cooler: Applying the Community-Supported Agriculture Model to Fisheries. Soc. Nat. Resour. 2014, 27, 88-106. [CrossRef]

48. Bolton, A.E.; Dubik, B.A.; Stoll, J.S.; Basurto, X. Describing the diversity of community supported fishery programs in North America. Mar. Policy 2016, 66, 21-29. [CrossRef]

49. Witter, A.; Stoll, J. Participation and resistance: Alternative seafood marketing in a neoliberalera. Mar. Policy 2017, 80, 130-140. [CrossRef]

50. Bush, S.R.; Bailey, M.; van Zwieten, P.; Kochen, M.; Wiryawane, B.; Doddema, A.; Mangunsong, S.C. Private provision of public information in tuna fisheries. Mar. Policy 2017, 77, 130-135. [CrossRef]

51. Lewis, S.G.; Boyle, M. The Expanding Role of Traceability in Seafood: Tools and Key Initiatives. J. Food Sci. 2017, 82, A13-A21. [CrossRef] [PubMed]

52. Barclay, K.; Miller, A. The sustainable seafood movement is a Governance concert, with the audience playing a key role. Sustainability 2018, 10, 180. [CrossRef]

53. Morgera, E.; Ntona, M. Linking small-scale fisheries to international obligations on marine technology transfer. Mar. Policy 2018, 93, 295-306. [CrossRef]

54. Qureshi, S. Are we making a Better World with Information and Communication Technology for Development (ICT4D) Research? Findings from the Field and Theory Building. Info. Tech. Dev. 2015, 511-522. [CrossRef]

55. Previero, M.; Gasalla, M.A. Mapping fishing grounds, resource and fleet patterns to enhance management units in data-poor fisheries: The case of snappers and groupers in the Abrolhos Bank coral-reefs (South Atlantic). Ocean Coast. Manag. 2018, 154, 83-95. [CrossRef]

56. Chuenpagdee, R.; Rocklin, D.; Bishop, D.; Hynes, M.; Greene, R.; Lorenzi, M.R.; Devillers, R. The global information system on small-scale fisheries (ISSF): A crowdsourced knowledge platform. Mar. Policy 2019, 101, 158-166. [CrossRef] 
57. Hordyk, A.; Ono, K.; Valencia, S.; Loneragan, N.; Prince, J. A novel length-based empirical estimation method of spawning potential ratio (SPR), and tests of its performance, for small-scale, data-poor fisheries. ICES J. Mar. Sci. 2015, 72, 217-231. [CrossRef]

58. Pita, C.; Villasante, S.; Pascual-Fernández, J.J. Managing small-scale fisheries under data poor scenarios: Lessons from around the world. Mar. Policy 2019, 101, 154-157. [CrossRef]

59. Rubio-Cisneros, N.T.; Moreno-Báez, M.; Glover, J.; Rissolo, D.; Sáenz-Arroyo, A.; Götz, C.; Salas, S.; Andrews, A.; Marín, G.; Morales-Ojeda, S.; et al. Poor fisheries data, many fishers, and increasing tourism development: Interdisciplinary views on past and current small-scale fisheries exploitation on Holbox Island. Mar. Policy 2019, 100, 8-20. [CrossRef]

60. De la Barra, P.; Iribarne, O.; Narvarte, M. Combining fishers' perceptions, landings and an independent survey to evaluate trends in a swimming crab data-poor artisanal fishery. Ocean Coast. Manag. 2019, 173, 26-35. [CrossRef]

61. Goti-Aralucea, L. Assessing the social and economic impact of small scale fisheries management measures in a marine protected area with limited data. Mar. Policy 2019, 101, 246-256. [CrossRef]

62. Tallman, R.F.; Roux, M.-J.; Martin, Z.A. Governance and assessment of small-scale data-limited Arctic Charr fisheries using productivity-susceptibility analysis coupled with life history invariant models. Mar. Policy 2019, 101, 187-197. [CrossRef]

63. Fischer, J.; Jorgensen, J.; Josupeit, H.; Kalikoski, D.; Lucas, C.M. Fishers' Knowledge and the Ecosystem Approach to Fisheries. Applications, Experiences and Lessons in Latin America; Food and Agriculture Organisation of the United Nations: Rome, Italy, 2015.

64. Parsons, M.; Fisher, K.; Nalau, J. Alternative approaches to co-design: Insights from indigenous/academic research collaborations. Curr. Opin. Environ. Sustain. 2016, 20, 29-105. [CrossRef]

65. Barnes, M.L.; Mbaru, E.; Muthiga, N. Information access and knowledge exchange in co-managed coral reef fisheries. Biol. Conserv. 2019, 238, 108198. [CrossRef]

66. Rathwell, K.J.; Armitage, D.; Berkes, F. Bridging knowledge systems to enhance governance of the environmental commons: A typology of settings. Int. J. Commons 2015, 9, 851-880. [CrossRef]

67. Sabu, M.; Shaijumon, C.S.; Rajesh, R. Factors influencing the adoption of ICT tools in Kerala marine fisheries sector: An analytic hierarchy process approach. Technol. Anal. Strateg. Manag. 2018, 30, 866-880. [CrossRef]

68. Sein, M.K.; Thapa, D.; Hatakka, M.; Saebø, Ø. A holistic perspective on the theoretical foundations for ICT4D research. Inf. Technol. Dev. 2019, 25, 7-25. [CrossRef]

69. Brown, A.N.; Skelly, H.J. How Much Evidence Is There Really ? Mapping the Evidence Base for ICTD Interventions. Inf. Technol. Int. Dev. 2019, 15, 16-33.

70. Cinnamon, J. Data inequalities and why they matter for development. Inf. Technol. Dev. 2019. [CrossRef]

71. Cibangu, S.K. Marginalization of indigenous voices in the information age: A case study of cell phones in the rural Congo. Inf. Technol. Dev. 2019. [CrossRef]

72. Chipidza, W.; Leidner, D. A review of the ICT-enabled development literature: Towards a power parity theory of ICT4D. J. Strateg. Inf. Syst. 2019, 28, 145-174. [CrossRef]

73. Jacobs, C.; Rivett, U.; Chemisto, M. Developing capacity through co-design: The case of two municipalities in rural South Africa. Inf. Technol. Dev. 2018, 25, 204-226. [CrossRef]

74. Pinkerton, E. Hegemony and resistance: Disturbing patterns and hopeful signs in the impact of neoliberal policies on small-scale fisheries around the world. Mar. Policy 2017, 80, 1-9. [CrossRef]

75. Pinkerton, E.; Davis, R. Neoliberalism and the politics of enclosure in North American small-scale fisheries. Mar. Policy 2015, 61, 303-312. [CrossRef]

76. Bess, R. New Zealand's indigenous people and their claims to fisheries resources. Mar. Policy 2001, 25, 23-32. [CrossRef]

77. Olson, J. Understanding and contextualizing social impacts from the privatization of fisheries: An overview. Ocean Coast. Manag. 2011, 54, 353-363. [CrossRef]

78. Carothers, C. A survey of US halibut IFQ holders: Market participation, attitudes, and impacts. Mar. Policy 2013, 38, 515-522. [CrossRef]

79. Hardin, G. The Tragedy of the Commons. Source Sci. New Ser. 1968, 162, 1243-1248.

80. Mansfield, B. "Modern" industrial fisheries and the crisis of overfishing. In Global Political Ecology; Peet, R., Robbins, P., Watts, M., Eds.; Routledge: London, UK, 2010; pp. 98-113. 
81. Barnett, A.J.; Messenger, R.A.; Wiber, M.G. Enacting and contesting neoliberalism in fisheries: The tragedy of commodifying lobster access rights in Southwest Nova Scotia. Mar. Policy 2017, 80, 60-68. [CrossRef]

82. Breslow, S.J. Accounting for neoliberalism: “Social drivers" in environmental management. Mar. Policy 2015, 61, 420-429. [CrossRef]

83. Davis, A.; Ruddle, K. Massaging the Misery: Recent Approaches to Fisheries Governance and the Betrayal of Small-Scale Fisheries. Hum. Organ. 2012, 71, 244-254. [CrossRef]

84. Said, A.; Tzanopoulos, J.; Macmillan, D. Bluefin tuna fishery policy in Malta: The plight of artisanal fishermen caught in the capitalist net Wildlife Trade View project Investigating tiger poaching in the Bangladesh Sundarbans View project Bluefin tuna fishery policy in Malta: The plight of art. Mar. Policy 2016, 73, 27-34. [CrossRef]

85. Gallardo-Fernández, G.L.; Saunders, F. “Before we asked for permission, now we only give notice": Women's entrance into artisanal fisheries in Chile. Marit. Stud. 2018, 17, 177-188. [CrossRef]

86. Peterson, M.N.; Von Essen, E.; Hansen, H.P.; Peterson, T.R. Illegal fishing and hunting as resistance to neoliberal colonialism. Crimelaw. Soc. Chang. 2017, 67, 401-413. [CrossRef]

87. Thornton, T.F.; Hebert, J. Neoliberal and neo-communal herring fisheries in Southeast Alaska: Reframing sustainability in marine ecosystems. Mar. Policy 2015, 61, 366-375. [CrossRef]

88. Gallardo Fernández, G.L.; Stotz, W.; Aburto, J.; Mondaca, C.; Vera, K. Emerging commons within artisanal fisheries. The Chilean territorial use rights in fisheries (TURFs) within a broader coastal landscape. Int. J. Commons 2011, 5, 459. [CrossRef]

89. Altieri, M.A.; Rojas, A. Ecological Impacts of Chile's Neoliberal Policies, with Special Emphasis on Agroecosystems. Environ. Dev. Sustain. 1999, 1, 55-72. [CrossRef]

90. St Martin, K. The Difference that Class Makes: Neoliberalization and Non-Capitalism in the Fishing Industry of New England. Antipode 2007, 39, 527-549. [CrossRef]

91. Altamirano-Jiménez, I. The sea is our bread: Interrupting green neoliberalism in Mexico. Mar. Policy 2017, 80, 28-34. [CrossRef]

92. Fung, A.; Wright, E.O. Deepening Democracy: Innovations in Empowered Participatory Governance. Polit. Soc. 2001, 29, 5-41. [CrossRef]

93. Emirbayer, M.; Noble, M. The peculiar convergence of Jeffrey Alexander and Erik Olin Wright. Theory Soc. 2013, 42, 617-645. [CrossRef]

94. Box, R.C. Progressive Utopias Marcuse, Rorty, and Wright. Adm. Theory Prax. 2012, 34, 60-84.

95. Wright, E.O. Transforming Capitalism through Real Utopias. Ir. J. Sociol. 2013, 21, 6-40. [CrossRef]

96. Brie, M. Review of Envisioning Real Utopias by Erik Olin Wright. Int. Crit. Thought 2011, 1, $462-468$. [CrossRef]

97. Williamson, T. Emancipatory Politics, Emancipatory Political Science: On Erik Olin Wright's Envisioning Real Utopias. New Polit. Sci. 2012, 34, 386-395. [CrossRef]

98. Wright, E.O. Basic Income as a Socialist Project. Basic Income Stud. 2006, 1. [CrossRef]

99. Mccabe, C. Transforming capitalism through real utopias: A critical engagement. Ir. J. Sociol. 2013, $21,51-61$. [CrossRef]

100. Khalfani, K.A.; Zuberi, T. Racial classification and the modern census in South Africa, 1911-1996. Race Soc. 2001, 4, 161-176. [CrossRef]

101. Statistics South Africa. Statistics South Africa. Census. 2011. Available online: http://www.statssa.gov.za/ ?page_id=4286\&id=14 (accessed on 31 May 2019).

102. Fabinyi, M.; Foale, S.; Macintyre, M. Managing inequality or managing stocks? An ethnographic perspective on the governance of small-scale fisheries. Fish Fish. 2015, 16, 471-485. [CrossRef]

103. Nthane, T.; Raemaekers, S.; Waldeck, N. New Policy Can Bring Unity to Lamberts Bay Fishers. Masifundise Development Trust, 20 May 2015. Available online: http://masifundise.org/new-policy-can-bring-unity-tolamberts-bay-fishers/ (accessed on 31 May 2019).

104. FAO. FAO Fishery Country Profile-The Republic of South Africa; Food and Agricultural Organisation of the United Nations: Rome, Italy, 2003.

105. Saunders, F.P.; Gallardo-ferna, G.L.; Van Tuyen, T.; Raemaekers, S.; Marciniak, B.; Plá, R.D. Transformation of small-scale fisheries - Critical transdisciplinary challenges and possibilities. Curr. Opin. Environ. Sustain. 2016, 20, 26-31. [CrossRef] 
106. Newing, H.S. Conducting Research in Conservation: A Social Science Perspective, 1st ed.; Newing, H.S., Ed.; Routledge: New York, NY, USA, 2011; ISBN 9780415457910.

107. Miles, M.B.; Huberman, A.M.; Saldaña, J. Qualitative Data Analysis: A Methods Sourcebook, 3rd ed.; Huberman, M., Miles, M.B., Saldanña, J., Eds.; SAGE Publications Ltd: New York, NY, USA, 2014; ISBN 148332379X.

108. Hara, M.M. Analysis of South African Commercial Traditional Linefish Snoek Value Chain. Mar. Resour. Econ. 2014, 29, 279-299. [CrossRef]

109. González-Mon, B.; Bodin, Ö.; Crona, B.; Nenadovic, M.; Basurto, X. Small-scale fish buyers' trade networks reveal diverse actor types and differential adaptive capacities. Ecol. Econ. 2019, 164, 106338. [CrossRef]

110. Crona, B.I.; Basurto, X.; Squires, D.; Gelcich, S.; Daw, T.M.; Khan, A.; Havice, E.; Chomo, V.; Troell, M.; Buchary, E.A.; et al. Towards a typology of interactions between small-scale fisheries and global seafood trade. Mar. Policy 2016, 65, 1-10. [CrossRef]

111. Kininmonth, S.; Crona, B.; Bodin, Ö.; Vaccaro, I.; Chapman, L.J.; Chapman, C.A. Microeconomic relationships between and among fishers and traders influence the ability to respond to social-ecological changes in a small-scale fishery. Ecol. Soc. 2017, 22. [CrossRef]

112. Wamukota, A.; Brewer, T.D.; Crona, B. Market integration and its relation to income distribution and inequality among fishers and traders: The case of two small-scale Kenyan reef fisheries. Mar. Policy 2014, 48, 93-101. [CrossRef]

113. Drury O'Neill, E.; Crona, B. Assistance networks in seafood trade - A means to assess benefit distribution in small-scale fisheries. Mar. Policy 2017, 78, 196-205. [CrossRef]

114. Drury O'Neill, E.; Crona, B.; Ferrer, A.J.G.; Pomeroy, R.; Jiddawi, N.S. Who benefits from seafood trade? A comparison of social and market structures in small-scale fisheries. Ecol. Soc. 2018, 23. [CrossRef]

115. Stoll, J.S.; Dubik, B.A.; Campbell, L.M. Local seafood: Rethinking the direct marketing paradigm. Ecol. Soc. 2015, 20. [CrossRef]

116. Godwin, S.C.; Francis, F.T.; Howard, B.R.; Malpica-Cruz, L.; Witter, A.L. Towards the economic viability of local seafood programs: Key features for the financial performance of community supported fisheries. Mar. Policy 2017, 81, 375-380. [CrossRef]

117. Hamilton-Hart, N.; Stringer, C. Upgrading and exploitation in the fishing industry: Contributions of value chain analysis. Mar. Policy 2016, 63, 166-171. [CrossRef]

118. Bair, J. Analysing economic organization: Embedded networks and global chains compared. Econ. Soc. 2008, 37, 339-364. [CrossRef]

119. McCay, B.J.; Micheli, F.; Ponce-Díaz, G.; Murray, G.; Shester, G.; Ramirez-Sanchez, S.; Weisman, W. Cooperatives, concessions, and co-management on the Pacific coast of Mexico. Mar. Policy 2014, 44, 49-59. [CrossRef]

120. Léopold, M.; Thébaud, O.; Charles, A. The dynamics of institutional innovation: Crafting co-management in small-scale fisheries through action research. J. Environ. Manag. 2019, 237, 187-199.

121. Thapa, D.; Sein, M.K.; Sæbø, Ø. Building collective capabilities through ICT in a mountain region of Nepal: Where social capital leads to collective action. Inf. Technol. Dev. 2012, 18, 5-22. [CrossRef]

122. Beetham, D. Conditions for democratic consolidation. Rev. Afr. Polit. Econ. 1994, 21, 157-172. [CrossRef]

123. Brewer, J.F.; Molton, K.; Alden, R.; Guenther, C. Accountability, transformative learning, and alternate futures for New England groundfish catch shares. Mar. Policy 2017, 80, 113-122. [CrossRef]

124. Pinkerton, E. The role of moral economy in two British Columbia fisheries: Confronting neoliberal policies. Mar. Policy 2015, 61, 410-419. [CrossRef]

125. Langdon, S.J. Foregone harvests and neoliberal policies: Creating opportunities for rural, small-scale, community-based fisheries in southern Alaskan coastal villages. Mar. Policy 2015, 61, 347-355. [CrossRef]

126. Hursh, D.W.; Henderson, J.A. Contesting global neoliberalism and creating alternative futures. Discourse Stud. Cult. Polit. Educ. 2011, 32, 171-185. [CrossRef]

127. Marsden, T.; Franklin, A. Replacing neoliberalism: Theoretical implications of the rise of local food movements. Local Environ. 2013, 18, 636-641. [CrossRef]

128. Adhuri, D.S.; Rachmawati, L.; Sofyanto, H.; Hamilton-Hart, N. Green market for small people: Markets and opportunities for upgrading in small-scale fisheries in Indonesia. Mar. Policy 2016, 63, 198-205. [CrossRef]

129. Ruddle, K.; Davis, A.; Zone, P.U.; District, H.D.; Noi, H.; Nam, V. Human rights and neo-liberalism in small-scale fisheries: Conjoined priorities and processes. Mar. Policy 2013, 39, 87-93. [CrossRef] 
130. Sein, M.K.; Thapa, D.; Hatakka, M.; Saebo, O. What Theories do We Need to Know to Conduct ICT4D Research? SIG GlobDev: Dublin, Ireland, 2016.

(). (1)

(C) 2020 by the authors. Licensee MDPI, Basel, Switzerland. This article is an open access article distributed under the terms and conditions of the Creative Commons Attribution (CC BY) license (http://creativecommons.org/licenses/by/4.0/). 